\title{
Association of Microbiome with Oral Squamous Cell Carcinoma: A Systematic Review of the Metagenomic Studies
}

\author{
Lee Su Mun ${ }^{1}$, See Wye Lum ${ }^{1}$, Genevieve Kong Yuiin Sze ${ }^{1}$, Cheong Hock Yoong ${ }^{1}$, Kwek Ching Yung ${ }^{1}$, \\ Liong Kah Lok ${ }^{1}$ and Divya Gopinath $2, * \mathbb{D}$ \\ 1 School of Dentistry, International Medical University, Kuala Lumpur 57000, Malaysia \\ lee.sumun@student.imu.edu.my (L.S.M.); see.wyelum@student.imu.edu.my (S.W.L.); \\ genevieve.kongyuiin@student.imu.edu.my (G.K.Y.S.); cheong.hockyoong@student.imu.edu.my (C.H.Y.); \\ Kwek.chingyung@student.imu.edu.my (K.C.Y.); Liong.kahlok@student.imu.edu.my (L.K.L.) \\ 2 Oral Diagnosis and Surgical Sciences Division, School of Dentistry, International Medical University, \\ Kuala Lumpur 57000, Malaysia \\ * Correspondence: divyagopinath@imu.edu.my
}

\section{check for} updates

Citation: Su Mun, L.; Wye Lum, S.; Kong Yuiin Sze, G.; Hock Yoong, C.;

Ching Yung, K.; Kah Lok, L.;

Gopinath, D. Association of

Microbiome with Oral Squamous Cell

Carcinoma: A Systematic Review of the Metagenomic Studies. Int. J.

Environ. Res. Public Health 2021, 18,

7224. https://doi.org/10.3390/ ijerph18147224

Academic Editor: Fawad Javed

Received: 20 May 2021

Accepted: 1 July 2021

Published: 6 July 2021

Publisher's Note: MDPI stays neutral with regard to jurisdictional claims in published maps and institutional affiliations.

Copyright: (c) 2021 by the authors. Licensee MDPI, Basel, Switzerland. This article is an open access article distributed under the terms and conditions of the Creative Commons Attribution (CC BY) license (https:// creativecommons.org/licenses/by/ $4.0 /)$.

\begin{abstract}
The past decade has witnessed a surge in epidemiological studies that have explored the relationship between the oral microbiome and oral cancer. Owing to the diversity of the published data, a comprehensive systematic overview of the currently available evidence is critical. This review summarises the current evidence on the metagenomic studies on the oral microbiome in oral cancer. A systematic search was conducted in Medline and Embase databases to identify original studies examining the differences in the oral microbiome of oral cancer cases and controls. A total of twenty-six studies were identified that reported differences in microbial abundance between oral squamous cell carcinoma (OSCC) and controls. Although almost all the studies identified microbial dysbiosis to be associated with oral cancer, the detailed qualitative analysis did not reveal the presence/abundance of any individual bacteria or a consortium to be consistently enriched in OSCC samples across the studies. Interestingly, few studies reported a surge of periodontopathogenic taxa, especially Fusobacteria, whereas others demonstrated a depletion of commensal taxa Streptococci. Considerable heterogeneity could be identified in the parameters used for designing the studies as well as reporting the microbial data. If microbiome data needs to be translated in the future, to complement the clinical parameters for diagnosis and prognosis of oral cancer, further studies with the integration of clinical variables, adequate statistical power, reproducible methods, and models are required.
\end{abstract}

Keywords: oral cancer; microbiome; bacteriome; oral microbiota; metagenomics; microbiota; systematic review

\section{Introduction}

Oral squamous cell carcinoma (OSCC), commonly referred to as oral cancer, is the eighth-most prevalent cancer universally and has a 5-year survival rate of less than 50\% [1] In the United States alone, a total of 53,260 new cases and 10,750 deaths were projected for oral and oropharyngeal cancer in 2020 [2]. The global burden of oral and oropharyngeal cancer on the healthcare system is evident, hence, a clear systematic method of identifying oral cancer at the earliest possible stage is essential, which can ensure prompt treatment administration and higher cure rates. Principal risk factors for oral and oropharyngeal cancers include tobacco use and alcohol consumption [3]. Comparatively, other factors like genetics, oral health, low socioeconomic status, and human papillomavirus (only for oropharyngeal cancer) play a more minor role [4]. A proportion of oral cancers, especially in Asia, arise in the mucosa bearing long-standing pre-existing changes, visible as distinct clinical lesions, which are now collectively termed as "oral potentially malignant disorders (OPMD) [5,6]. 
Recently, multiple research studies have suggested that shifts in microbiota may disrupt the balance between microorganisms and humans, which, when coupled with risk factors, can lead to oncogenesis [7]. It is also hypothesized that bacteria may have a role in carcinogenesis by promoting chronic inflammation, preventing apoptosis, and generating oncogenic substances [8]. Furthermore, several cancers have been directly linked to bacterial infections; for instance: Helicobacter pylori and gastric carcinoma, Salmonella Typhi and gallbladder carcinoma, Salmonella Enterica and colon carcinoma, Chlamydia trachomatis and carcinoma of the cervix and ovaries [9]. Fusobacterium nucleatum (F. nucleatum) and porphyromonas gingivalis ( $P$. gingivalis) are some of the most studied oral bacteria with oncogenic properties in vitro [8].

In 2007, the National Institutes of Health (NIH) started the Human Microbiome Project (HMP) to study the human microbiome, which is defined as the collective genomes of the microbes within the human body. The role of the microbiome as a whole in various diseases, including oral diseases, has been increasingly recognized. Several studies have individually undertaken the task of collecting samples from oral/oropharyngeal cancer sites and profiling them using next-generation sequencing techniques as an attempt to identify the bacterial community associated with cancer. There have been attempts to assess if microbial dysbiosis, defined as any change in the composition of resident commensal communities, can be regarded as a causative factor or sequelae to oral/oropharyngeal cancer. However, the term "dysbiosis" is inconsistently and often vaguely utilized with a broad range of stochastic interpretations [7]. Overall, our current insights into the exact relationships between the oral microbiome and OSCC remains limited, and a meaningful consensus has yet to be reached regarding cancer-associated changes in species abundance and diversity. It is unclear whether we can identify individual microbes or microbial signatures consisting of a group of microorganisms that are consistently depleted or elevated in OSCC across the patients. Thus, the current article aims to compile the updated evidence regarding the bacterial association with OSCC with a systematic review of published epidemiological studies that have investigated an association of the oral microbiome and OSCC.

\section{Materials and Methods}

\subsection{Design}

A systematic literature search was conducted independently by two authors (S.W.L., L.S.M.) to identify original observational studies examining the differences in the oral microbial community as a whole in oral samples in patients with oral cancer and healthy controls using next-generation sequencing techniques. This systematic review adheres to the PRISMA (Preferred Reporting Items for Systematic Reviews and Meta-Analyses) guidelines.

\subsection{Data Sources and Search Strategy}

The strategies and criteria of inclusion were discussed among the authors beforehand. Published literature was systematically searched without date limitations until October 2020, using specific search terms through two databases, Medline and Embase, to discover articles related to oral cancer and oral microbiome. The search strategy comprised of the following words: "mouth neoplasms", "oral carcinoma", "OSCC", "oral malignancy", "uncontrol growth", "bacteria", "microbiota", "microbiome", "metagenomics", "metagenome", "sequence analysis", "DNA", "RNA", "ribosomal", and, "16S". Boolean operators "AND" as well as "OR" were used for more focused and productive results. The results were again confined to the English language and humans. The detailed search strategy is provided in Supplementary Table S1. Manual searches for references of the included articles were also conducted to avoid the omission of relevant articles. The authors initially screened the articles for eligibility based on the titles and abstracts, and subsequently, the selected articles underwent a full-text review. 


\subsection{Eligibility Criteria}

The studies included were original observational studies that met the following inclusion criteria;

Inclusion criteria: Studies that investigated the oral microbiome by profiling the genome of the whole microbial community through the metagenomic sequencing of oral samples from OSCC cases, relative to controls.

Exclusion criteria: Culture-based studies, papers from conferences or congresses, systematic reviews, and case reports were excluded. Articles other than the English language and human subjects were again excluded.

The PICO question for the review was as follows:

Population: Patients with OSCC

Intervention: Metagenomic sequencing studies which investigated the whole oral microbial community (microbiome). OSCC.

Control: Healthy control samples without any clinical or histological evidence of

Outcome: Microbial diversity and the relative abundance of various oral bacteria.

\subsection{Study Selection and Data Extraction}

Two authors screened the studies and those that did not meet the inclusion criteria were excluded. Any disagreement between authors was resolved through discussion. Data extraction was undertaken by specified authors using a pre-designed data extraction excel sheet. The following parameters were collected from each study:

i. study characteristics-author, year, country, study design, sample details;

ii. outcomes-diversity and richness, relative abundances of various taxa and microbial functions;

iii. methodology—DNA extraction, amplification, sequencing platforms, and reference.

\subsection{Risk of Bias Assessment}

The adjusted Newcastle-Ottawa Scale was used to assess the risk of bias, as described previously $[10,11]$, as the selected studies were non-randomized case-control studies $[10,11]$ (Supplementary Table S2).

\section{Results}

\subsection{Study Characteristics}

A total of twenty-six articles were included for review; a detailed flow chart of the selection process is provided in Figure 1. The characteristics of the selected studies are described in detail in Table 1. Of the twenty-six studies, ten were from the United States of America [12-21], four were from China [22-25], three were from Taiwan [7,26,27], two were from India [28,29], and others were from Yemen [30], Malaysia [31], Australia [32], Japan [33,34], Sri Lanka [35], and New Zealand [36]. The study design for all the studies was cross-sectional, except for one which employed a prospective methodology [19]. The total sample size of the selected studies ranged from 5 to 383, with the number of cases ranging from 3 to 249 and the number of controls ranging from 2 to 242 . Collectively, there were 1441 cases and 1368 controls represented in a total of 26 publications. The average age of the subjects ranged from 18 to 81 years. The majority of the studies included both genders as the subjects except two studies which were restricted to male subjects only [12,35]. Other associated factors such as cigarette smoking, betel quid chewing, and alcohol use, HPV, etc., were investigated in fifteen of the selected studies [7,12,20,21,23,24,26-32,34,35]. The ability to compare or incorporate the results of individual studies was restricted by the extensive differences in various aspects of the studies. 

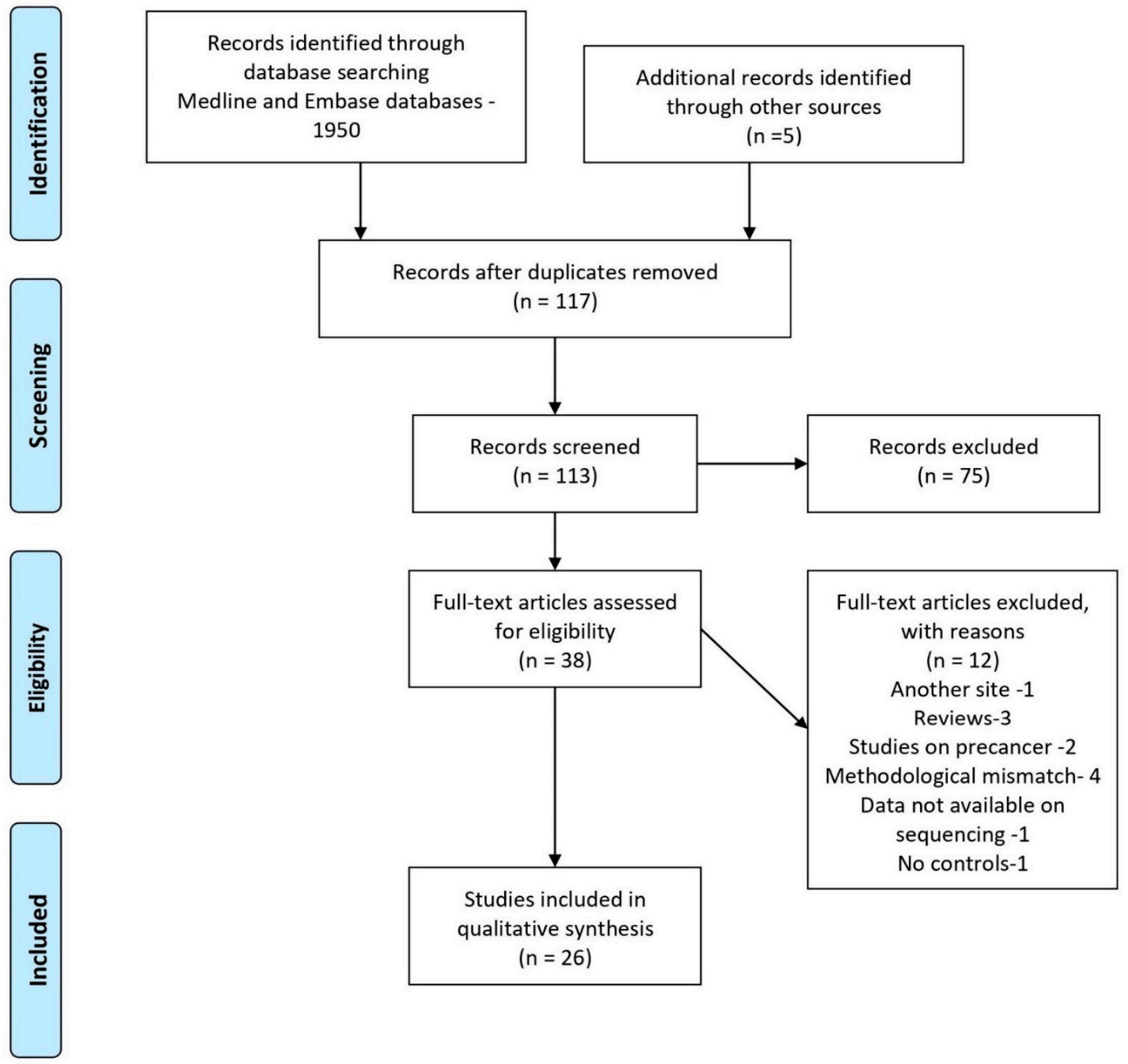

Figure 1. PRISMA flow chart for the selection of studies. 
Table 1. Summary of characteristics of epidemiological studies on the microbiome and oral cancer.

\begin{tabular}{|c|c|c|c|c|c|c|c|c|}
\hline No. & Author, Year & Sample Type & Age (Mean/Median) & Nature of Control & $\begin{array}{l}\text { Study Population } \\
\text { Size (Case, Control) }\end{array}$ & $\begin{array}{l}\text { Other Clinical } \\
\text { Features Studied }\end{array}$ & $\begin{array}{l}\text { Results: Diversity and } \\
\text { Richness }\end{array}$ & $\begin{array}{l}\text { Bacterial Taxa Associated with } \\
\text { Tumors and Controls }\end{array}$ \\
\hline 1 & $\begin{array}{l}\text { Pushalkar et al. } \\
2011[12]\end{array}$ & Saliva & Age: $>50$ & Healthy controls & $\begin{array}{l}\text { Case: } 3 \\
\text { Control: } 2\end{array}$ & $\begin{array}{l}\text { Smoking: at least } \\
\text { one pack of } \\
\text { cigarettes a day. } \\
\text { Alcohol: more than } \\
\text { five drinks a day }\end{array}$ & $\begin{array}{l}\text { Increase in diversity in the } \\
\text { control group }\end{array}$ & $\begin{array}{l}\text { Streptococcus, Gemella, Rothia, } \\
\text { Peptostreptococcus, Lactobacillus, } \\
\text { Porphyromonas in OSCC group. } \\
\text { Prevotella, Neisseria, Leptotrichia, } \\
\text { Capnocytophaga, Actinobacillus and } \\
\text { Oribacterium in the control group. }\end{array}$ \\
\hline 2 & $\begin{array}{l}\text { Schmidt et al. } \\
2014 \text { [13] }\end{array}$ & Oral swab & $\begin{array}{l}\text { Cancer: } 62 \\
\text { Control: } 31\end{array}$ & $\begin{array}{l}\text { Contralateral normal } \\
\text { regions of the oral } \\
\text { cavity }\end{array}$ & $\begin{array}{l}\text { Case: } 50 \\
\text { Control: } 20\end{array}$ & N/A & N/A & $\begin{array}{l}\text { Decreased relative abundance of } \\
\text { Streptococcus and Rothia in the tumor } \\
\text { group. } \\
\text { Increased relative abundance of } \\
\text { Fusobacterium in the tumor group. }\end{array}$ \\
\hline 3 & $\begin{array}{l}\text { Guerrero- } \\
\text { Preston et al. } \\
2016[14]\end{array}$ & Tissue and saliva & $\begin{array}{l}\text { OSCC: } 66 \\
\text { OPSCC: } 62 \\
\text { Control: N/A }\end{array}$ & $\begin{array}{l}\text { Healthy controls } \\
\text { without smoking } \\
\text { and drinking }\end{array}$ & $\begin{array}{l}\text { Case: } 19 \\
\text { Control: } 25\end{array}$ & N/A & $\begin{array}{l}\text { Decrease in richness and } \\
\text { diversity in cases } \\
\text { Significant increase of certain } \\
\text { Lactobacillus and Weeksellaceae } \\
\text { in HPV+ samples } \\
\text { Significant abundance of } \\
\text { Eikenella, Neisseria, and } \\
\text { Leptotrichia in HPV- samples }\end{array}$ & $\begin{array}{l}\text { Significant increase of Lactobacillus, } \\
\text { Strepcoccus, Staphylococcus and } \\
\text { Parvimonas in HNSCC group. } \\
\text { Significant abundance of Haemophilus, } \\
\text { Neisseria, Gemellaceae and } \\
\text { Aggregatibacter in the control group. }\end{array}$ \\
\hline 4 & $\begin{array}{l}\text { Al-Hebshi et al. } \\
2017 \text { [30] }\end{array}$ & Tissue & $\begin{array}{l}\text { Case: } 53.6 \pm 10.4 \\
\text { Controls: } 52.3 \pm 8.9\end{array}$ & $\begin{array}{l}\text { Healthy, gender- and } \\
\text { age-matched } \\
\text { controls }\end{array}$ & $\begin{array}{l}\text { Case: } 20 \\
\text { Control: } 20\end{array}$ & $\begin{array}{l}\text { Smoking: shammah } \\
\text { (smokeless tobacco) }\end{array}$ & $\begin{array}{l}\text { Similar species richness and } \\
\alpha \text {-diversity in both groups } \\
\text { (tissue biopsies) }\end{array}$ & $\begin{array}{l}\text { Significant abundance of } \\
\text { Fusobacterium in OSCC group. } \\
\text { Significant abundance of Streptococcus } \\
\text { and Rothia in the control group. } \\
\text { Significant abundance of }\end{array}$ \\
\hline 5 & $\begin{array}{l}\text { Banerjee et al. } \\
2017 \text { [16] }\end{array}$ & Tissue (FFPE) & N/A & $\begin{array}{l}\text { Adjacent } \\
\text { non-tumorous } \\
\text { tissues, healthy } \\
\text { controls }\end{array}$ & $\begin{array}{l}\text { Cases: } 100 \\
\text { Controls: } 40\end{array}$ & N/A & $\mathrm{N} / \mathrm{A}$ & $\begin{array}{l}\text { Proteobacteria Brevundimonas, } \\
\text { Actinobacteria Mobiluncus, Frateuria, } \\
\text { Caulobacter, Actinomyces and } \\
\text { Aeromonas in OSCC group. } \\
\text { Significant abundance of Actinomyces } \\
\text { in the control group. }\end{array}$ \\
\hline 6 & $\begin{array}{l}\text { Bornigen et al. } \\
2017 \text { [17] }\end{array}$ & Oral rinse & 58 & Healthy controls & $\begin{array}{l}\text { Case: } 121 \\
\text { Control: } 242\end{array}$ & N/A & $\begin{array}{l}\text { Increase in diversity in } \\
\text { smokers }\end{array}$ & $\begin{array}{l}\text { Significant abundance of Dialister in } \\
\text { the oral cancer group. } \\
\text { Significant decrease of Actinomycetales } \\
\text { and Lactobacillales in the oral cancer } \\
\text { group. }\end{array}$ \\
\hline
\end{tabular}


Table 1. Cont.

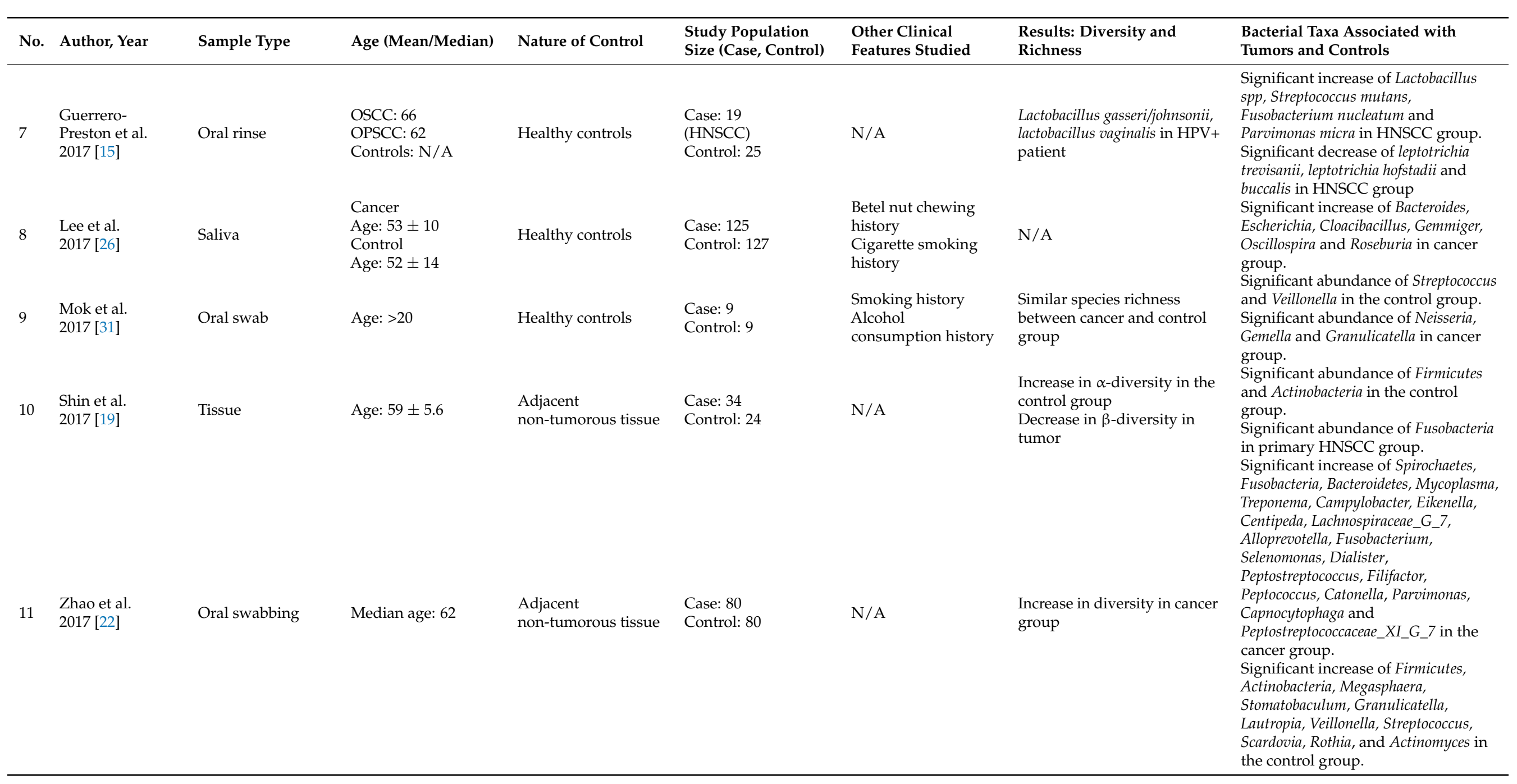


Table 1. Cont.

\begin{tabular}{|c|c|c|c|c|c|c|c|c|}
\hline No. & Author, Year & Sample Type & Age (Mean/Median) & Nature of Control & $\begin{array}{l}\text { Study Population } \\
\text { Size (Case, Control) }\end{array}$ & $\begin{array}{l}\text { Other Clinical } \\
\text { Features Studied }\end{array}$ & $\begin{array}{l}\text { Results: Diversity and } \\
\text { Richness }\end{array}$ & $\begin{array}{l}\text { Bacterial Taxa Associated with } \\
\text { Tumors and Controls }\end{array}$ \\
\hline 12 & $\begin{array}{l}\text { Hayes et al. } \\
2018 \text { [18] }\end{array}$ & Oral rinse & $\begin{array}{l}\text { Case: } 60-70 \\
\text { Control: } 60-70\end{array}$ & Healthy controls & $\begin{array}{l}\text { Case: } 129 \\
\text { Control: } 254\end{array}$ & N/A & N/A & $\begin{array}{l}\text { Significant increase of Actinobacteria } \\
\text { in HNSCC group. Significant } \\
\text { decrease of Parvimonas micra and } \\
\text { Neisseria sicca in oral cancer group. } \\
\text { Significant decrease of Genus } \\
\text { Corynebacterium up to order } \\
\text { Corynebacteriales, genus Kingella up to } \\
\text { phylum Proteobacteria, Prevotella } \\
\text { nanceiensis, Capnocytophaga leadbetteri } \\
\text { and Selenomonas sputigena in HNSCC } \\
\text { group. Significant increase of } \\
\text { Actinomyces (oral taxon_170) in the } \\
\text { oral cancer group. }\end{array}$ \\
\hline 13 & $\begin{array}{l}\text { Hsiao et al. } \\
2018 \text { [27] }\end{array}$ & Saliva & $\begin{array}{l}\text { Cases: } \geq 20 \\
\text { Control: } \geq 20\end{array}$ & Healthy controls & $\begin{array}{l}\text { Case: } 138 \\
\text { Control: } 151\end{array}$ & $\begin{array}{l}\text { Betel nut chewing } \\
\text { history } \\
\text { Cigarette smoking } \\
\text { history } \\
\text { Alcohol } \\
\text { consumption history } \\
\text { Oral hygiene status }\end{array}$ & $\begin{array}{l}\text { Significant increase of } \\
\text { Prevotella intermedia in } \\
\text { alcohol consumers and betel } \\
\text { nut chewers } \\
\text { Significant increase of } \\
\text { F.nucleatum in smokers } \\
\text { Significant increase of } \\
\text { Prevotella tannerae and } \\
\text { F.nucleatum in poor dental } \\
\text { care group }\end{array}$ & $\begin{array}{l}\text { Significant increase of Prevotella } \\
\text { tannerae, F. nucleatum and Prevotella } \\
\text { intermedia in the cancer group. }\end{array}$ \\
\hline 14 & $\begin{array}{l}\text { Lim et al. } \\
2018 \text { [32] }\end{array}$ & Oral rinse & $\begin{array}{l}\text { Case: } 65 \\
\text { Control: } 20-60\end{array}$ & Healthy controls & $\begin{array}{l}\text { Case: } 63 \\
\text { Control: } 20\end{array}$ & $\begin{array}{l}\text { Smoking history } \\
\text { Alcohol } \\
\text { consumption history } \\
\text { HPV status }\end{array}$ & $\begin{array}{l}\text { Decrease in diversity in the } \\
\text { cancer group }\end{array}$ & $\begin{array}{l}\text { Significant increase of Oribacterium in } \\
\text { OCC and OPC group. } \\
\text { Significant decrease of Rothia, } \\
\text { Haemophilus, Corynebacterium, } \\
\text { Paludibacter, Porphyromonas, and } \\
\text { Capnocytophaga in OCC and OPC } \\
\text { group. } \\
\text { Significant increase of Actinomyces, } \\
\text { Parvimonas, Selenomonas, and } \\
\text { Prevotella in OCC group. } \\
\text { Significant increase of Haemophilus } \\
\text { and Gemella in HPV+ group. }\end{array}$ \\
\hline
\end{tabular}


Table 1. Cont.

\begin{tabular}{|c|c|c|c|c|c|c|c|c|}
\hline No. & Author, Year & Sample Type & Age (Mean/Median) & Nature of Control & $\begin{array}{l}\text { Study Population } \\
\text { Size (Case, Control) }\end{array}$ & $\begin{array}{l}\text { Other Clinical } \\
\text { Features Studied }\end{array}$ & $\begin{array}{l}\text { Results: Diversity and } \\
\text { Richness }\end{array}$ & $\begin{array}{l}\text { Bacterial Taxa Associated with } \\
\text { Tumors and Controls }\end{array}$ \\
\hline 15 & $\begin{array}{l}\text { Perera et al. } \\
2018 \text { [35] }\end{array}$ & Tissue & $\begin{array}{l}\text { Case: Age: } \\
61.00 \pm 9.5 \\
\text { Controls: Age: } 50.58 \\
\pm 13.5\end{array}$ & Healthy controls & $\begin{array}{l}\text { Case: } 25 \\
\text { Control: } 27\end{array}$ & $\begin{array}{l}\text { Betel nut chewing } \\
\text { history } \\
\text { Smoking history } \\
\text { Alcohol } \\
\text { consumption history } \\
\text { Oral hygiene and } \\
\text { periodontal status } \\
\text { Missing teeth }\end{array}$ & $\begin{array}{l}\text { Decrease in diversity in } \\
\text { cancer group }\end{array}$ & $\begin{array}{l}\text { Significant increase of Capnocytophaga, } \\
\text { Pseudomonas, Atopobium, } \\
\text { Campylobacter concisus, Prevotella } \\
\text { salivae, Prevotella loeschii, } \\
\text { Fusobacterium oral taxon 204, F. } \\
\text { nucleatum subsp. polymorphum, } \\
\text { Streptococcus dysgalactiae, Citrobacter } \\
\text { koseri, and Pseudomonas aeruginosa in } \\
\text { OSCC group. } \\
\text { Significant increase of Lautropia, } \\
\text { Staphylococcus, Propionibacterium, } \\
\text { Sphingomonas, Streptococcus } \\
\text { parasanguinis, Streptococcus mitis, } \\
\text { Streptococcus sp oral taxon 070, } \\
\text { Streptococcus sp oral taxon } 423, \\
\text { Streptococcus sp oral taxon 431, } \\
\text { Streptococcus agalactiae, Rothia } \\
\text { dentocariosa, Rothia mucilaginosa, } \\
\text { Lautropia mirabilis, Leptotrichia oral } \\
\text { taxon 225, and Staphylococcus } \\
\text { epidermidis in control group. }\end{array}$ \\
\hline 17 & $\begin{array}{l}\text { Yang C. et al. } \\
2018[7]\end{array}$ & Oral rinse & $\begin{array}{l}\text { Case Age: } 50-60 \\
\text { Control: Age: } 35-35\end{array}$ & Healthy controls & $\begin{array}{l}\text { Case: } 197 \\
\text { Control: } 51\end{array}$ & $\begin{array}{l}\text { TNM stage } \\
\text { Betel nut chewing } \\
\text { history } \\
\text { Alcohol } \\
\text { consumption history }\end{array}$ & $\begin{array}{l}\text { Significant increase of F. alocis } \\
\text { in smokers }\end{array}$ & $\begin{array}{l}\text { Significant abundance of } \\
\text { Fusobacterium periodonticum, } \\
\text { Parvimonas micra, Streptococcus } \\
\text { constellatus, Haemophilus influenza and } \\
\text { Filifactor alocis in OSCC (Stage 4) } \\
\text { group. } \\
\text { Significant abundance of Haemophilus } \\
\text { parainfluenzae, Porphyromonas pasteri, } \\
\text { Veillonella parvula and Actinomyces } \\
\text { odontolyticus in control group. }\end{array}$ \\
\hline
\end{tabular}


Table 1. Cont.

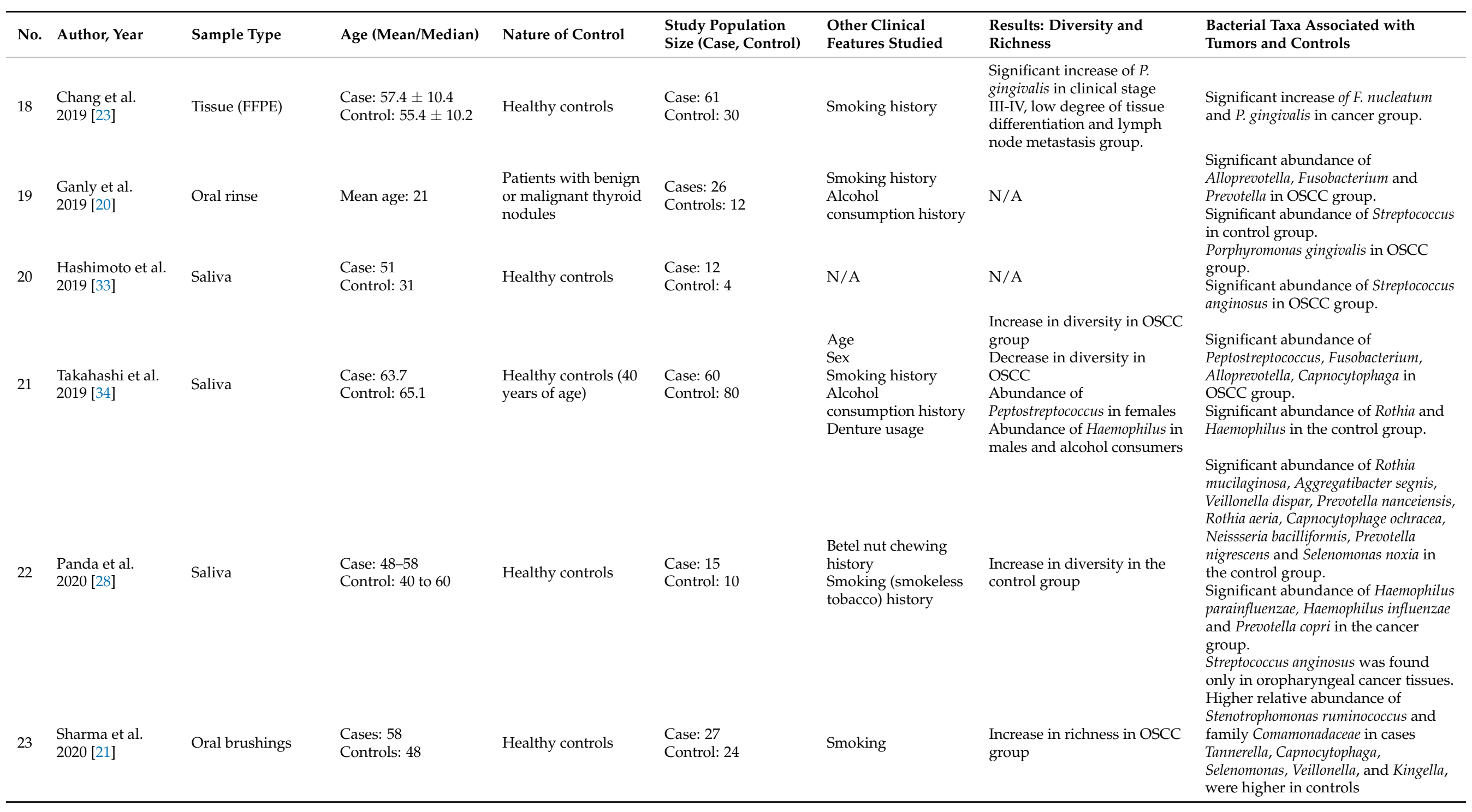


Table 1. Cont.

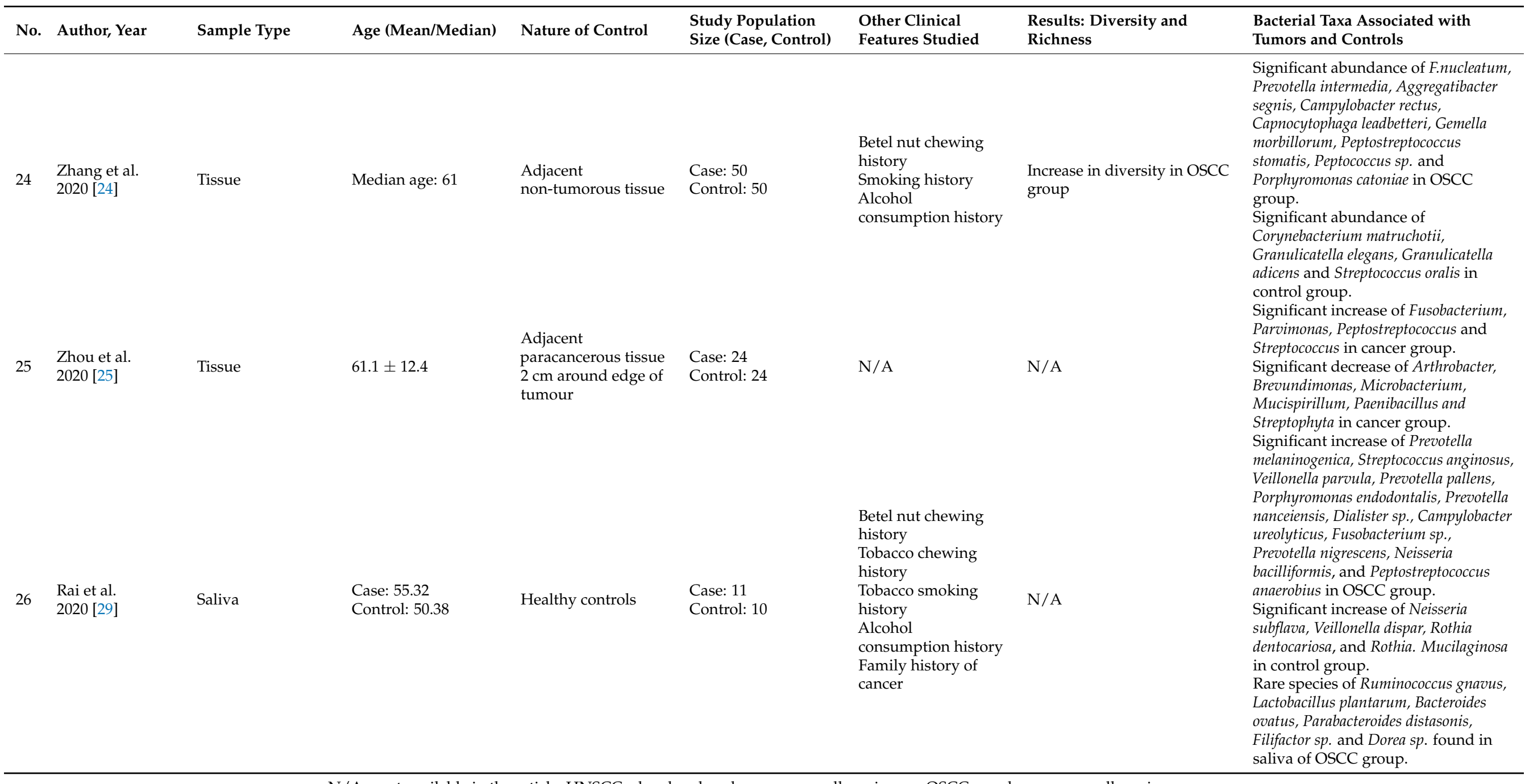




\subsection{Sample Collection and Measurement}

Different types of samples were used to characterise the oral microbiome found in patients with oral cancer, as described in Table 1, including saliva [12,14,26-28,33,34,36], swabs from the oral cavity $[13,22,29,31]$, the tumor tissue $[14,16,19,23-25,30,35]$, oral brushings [21], and oral rinses $[15,17,20,32]$. Samples from normal healthy individuals, as well as the patient's own mucosa, were utilized as controls in the included studies. Those studies which used samples from normal healthy individuals as controls had varied matching criteria which included site [12,28,30,33,35], age [26,30], and gender [12,30,35]. The microbiome from the tumor tissues was compared with the adjacent non-tumorous tissues from the same patients $[16,19,22,24,25]$, non-tumorous tissues from the contralateral side of the same patients [16,24], with fibroepithelial polyps from healthy controls [35], and healthy tissues from normal healthy individuals $[23,30]$. Salivary samples utilized included stimulated saliva samples $[12,14,26-28,33,34,36]$ and unstimulated saliva samples $(29,36)$ from patients with OSCC compared with those from healthy controls. Few studies utilized oral swabs from oral lesions compared with those from the contralateral normal regions of the oral cavity $[13,22]$ or with the oral swabs from normal healthy individuals [31]. Other types of samples used were oral brushings from buccal mucosa in both cases and controls [21], oral rinses from patients with oral cavity cancer compared with normal healthy individuals $[15,17,32]$, or oral rinses from patients with oral cancer compared with normal healthy individuals [20].

\subsection{Techniques of DNA Extraction and Sequencing \\ 3.3.1. DNA Extraction}

The numerous methods that were employed to extract DNA from the oral samples are listed in Table 2. The different kinds of commercial DNA kits used were: DNA Purification Kit (Epicenter) [12], RNeasy Mini, RNA Isolation Kit [19], DNeasy Blood and Tissue Kit (Qiagen) [13,28,29], DDK DNA Isolation Kit [30], All Prep DNA/RNA FFPE Kit [16], QIAsymphony Virus/Bacteria Midi Kit [17], PowerSoil DNA Isolation Kit, MoBio [18], QIAamp DNA Mini Kit [22], QIAamp DNA Blood Mini Kit (Qiagen) [26], QIAamp DNA Microbiome Kit [7], QIAampFast DNA Stool Mini Kit [23], QIAGEN QIAamp MinElute Virus Spin Kit [27], Commercial Kit (EURx) [31], Maxwell ${ }^{\circledR} 16$ LEV blood DNA Kit [32], Gentra Puregene Tissue Kit (Qiagen) [35], DNA Purification Kit (Qiagen), and TIANamp Swab DNA Kit [24]. In addition, DNA extraction by the traditional phenol-chloroform method was also utilised by three studies $[14,15,36]$. 
Table 2. Summary of techniques of DNA extraction, amplification, and sequencing, and reference databases.

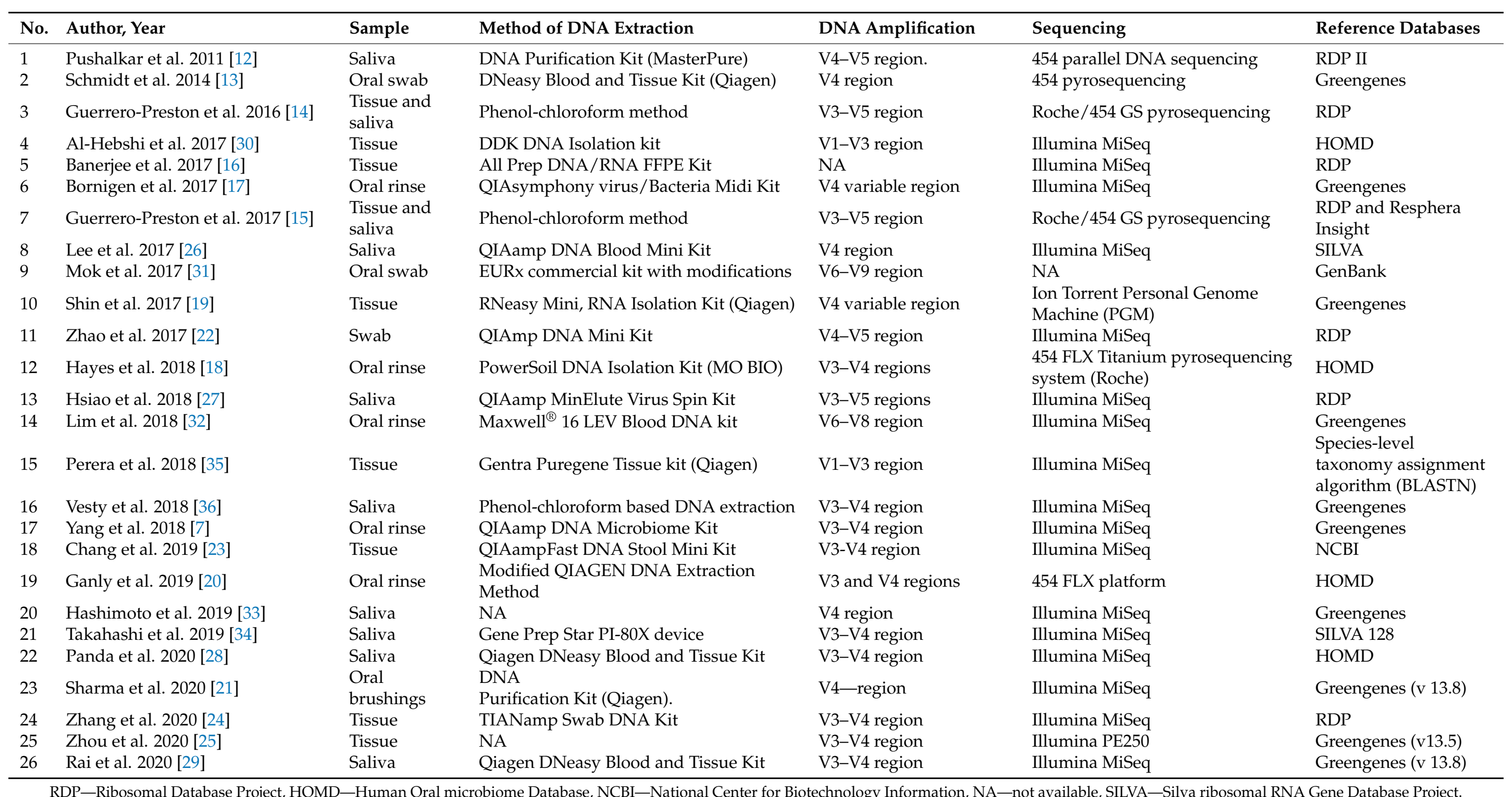

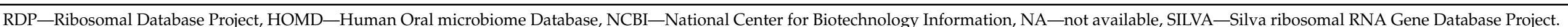




\subsubsection{DNA Amplification, Sequencing, and Reference Databases}

DNA amplification has been carried out by targeting different hypervariable regions of bacterial $16 \mathrm{~S}$ rRNA genes in these studies. Some study focused only on a single variable region such as $\mathrm{V} 4[13,17,19,21,26,33]$ while some focused on multiple regions for instance V1-V3 [30,35], V3-V4 [7,18,20,23-25,28,29,34,36], V3-V5 [14,15,27], V4-V5 [12,22], V6-V8 [32], and V6-V9 [31]. After DNA amplification was completed, DNA sequencing was implemented. The majority of these studies carried out sequencing by using the Illumina MiSeq system $[7,16,17,21-24,26,28-30,32-36]$. The second most common technique used was 454 pyrosequencing $[12-15,18,20]$. The Illumina PE250 platform was used by Zhou et al. 2020 [25]. Several different reference databases were utilized for sequencing alignment including GenBank [31], Ribosomal Database Project (RDP) [12,14-16,22,24,27], Human Oral Microbiome Database (HOMD) [7,18,30,33,36], Greengenes [13,16,19-21,25,28,29,32], SILVA [26,34], NCBI [7,23], BLASTN [35], and Resphera Insight [15].

\subsection{Microbial Diversity and Abundance}

Diversity can be categorized into alpha diversity and beta diversity. Alpha diversity is a local measure that is comparable within samples. In contrast, beta diversity shows differences in the composition of organisms among different individuals. In our review, only twelve out of twenty-six articles reported the diversity between diseased and healthy controls, regardless of healthy humans or healthy samples from cancer patients. Two articles did not report any significant differences in microbial richness and diversity between the cancer groups and control groups [30,31]. Four studies discovered greater richness and diversity in cancerous tissues or samples $[21,22,24,34]$. On the other hand, higher richness and diversity in controls were reported in another six studies [12,14,19,28,32,35]. Among smokers, it was found that patients with head and neck cancer had lower richness, but higher interindividual microbiome variation compared to healthy controls [21].

\subsection{Microbial Abundance}

\subsubsection{Phyla}

Most of the studies identified Firmicutes as the most abundant phyla in each subgroup (cancerous and healthy) in comparison with other phyla, including Proteobacteria, Bacteroidetes, and Fusobacteria. These phyla were also discovered in high proportions in cancer tissues, precancerous tissues, and subgingival plaque of OSCC patients [23]. In comparison to cancer samples, phylum Firmicutes was found to have a lower abundance in oral tissues samples of healthy individuals [19]. Another study reported that phylum Bacteriodetes were found more commonly in oral rinse samples of healthy controls in comparison with patients who were diagnosed with oral cavity or oropharyngeal cancers [16]. Another study reported that phylum Bacteroidetes was predominant in the OSCC group when compared to the oral leukoplakia group [33].

\subsubsection{Classes and Family}

Very few studies have described the microbial profile in terms of classes. At the class level, the predominant bacteria in all saliva samples (cancerous, healthy) were Betaproteobacteria, Bacteroidia, Actinobacteria, Bacilli, Fusobacteriia, TM7-3, Clostridia, and Gammaproteobacteria [28]. A higher relative abundance of family Comamonadaceae was reported in oral cancer cases from the North American cohort [21].

\subsubsection{Genera}

Numerous studies have reported the presence of bacteria from different genera in various types of samples from diseased patients and disease-free controls. Streptococcus was found to be the most predominant genus across cancer patients and healthy controls in several studies. Few studies stated that genus Streptococcus showed the greatest abundance in healthy controls $[28,31]$. Fusobacterium was reported to be abundant in cancer patients by 
quite a number of studies $[7,13,15,20,22-25,27,29,30,32,34,35]$. Genus Prevotella was found to be another one of the most abundant genera in cancer patients [27,29,35].

\subsubsection{Species}

Only a few studies had reported microbiome abundance at the species level. The higher abundance of Prevotella melaninogenica and Veillonella parvula in cancerous tissues was also reported by Rai et al. 2020 [29]. A study from Taiwan discovered that the saliva of patients diagnosed with OSCC exhibited a predominance of Prevotella tennerae, F. nucleatum and Prevotella intermedia but a lower abundance of Streptococcus tigurinus [27]. In the oral rinses taken from subjects with head and neck cancer, Lactobacillus spp., Streptococcus mutans, Fusobacterium nucleatum and Parvimonas micra were in significantly high abundance [15]. Chang et al. stated that the composition of bacterial species was similar in cancerous tissues, paracancerous tissues and subgingival plaques [23].

\subsection{Microbial Association with other Clinical Factors}

Guerrero-Preston et al. previously reported that Veilonella, Megasphaera, and Anaerolinaea were predominant in HPV-positive tumors and could be potential biomarkers for HPV associated oral cavity cancers [14]. Another study reported that oral rinses of HPV positive oral cancer patients were rich in Lactobacillus gasseri and Lactobacillus vaginalis [15]. A few studies investigated the association between past smoking habits and the cancer microbiome. However, no consistent effects on microbial proportion could be noted. Other clinical and environmental factors, including alcohol consumption and betel nut use, did not show any significant evidence of associations with oral cancer [17]. Takahashi et al. discovered a greater abundance of Peptostreptococcus and a reduced proportion of Haemophilus in saliva samples of females in comparison with males [34].

\subsection{Microbial Functions}

Seven studies reported the predicted functions of the microbiome with the help of advanced bioinformatics software. These programs help to identify the potential functions of these microbes from the whole genome sequences in the established databases. Three studies revealed a notable increase in lipopolysaccharide synthesis in the microbiome associated with oral cancer $[17,30,35]$, whereas four studies reported alterations in amino acid metabolism $[7,22,25,28]$. These have been listed in Table 3 .

Two studies reported an increase in genes associated with glucose metabolism in the control groups [30,35]. On the contrary, Yang et al. found carbohydrate metabolism to increase with OSCC staging [7]. Sharma et al. reported bacterial metabolic pathways mainly involved in amine and xenobiotic degradation to be more prevalent in cases and sugar degradation pathways in controls [21]. Zhao et al. reported the downregulation of pathways related to membrane transport and upregulation of genes associated with cytoskeletal proteins in oral cancer [22].

Table 3. Summary of highlighted Microbial functions.

\begin{tabular}{|c|c|c|c|}
\hline No. & Author, Year & Sample & Microbial Functions Associated with Tumors and Controls \\
\hline 1 & Zhao et al. 2017 [22] & Swabs & $\begin{array}{l}\text { Translation, metabolism of cofactors and vitamins, metabolism of terpenoids } \\
\text { and polyketides, replication and repair in cases }\end{array}$ \\
\hline 2 & Al-Hebshi et al. 2017 [30] & Tissue & $\begin{array}{l}\text { Bacterial mobility, flagellar assembly, bacterial chemotaxis, and LPS } \\
\text { biosynthesis in cases } \\
\text { DNA repair, glycolysis/gluconeogenesis, and biosynthesis of amino acids in } \\
\text { controls }\end{array}$ \\
\hline 3 & Perera et al. 2018 [35] & Tissue & $\begin{array}{l}\text { Lipopolysaccharide biosynthesis, peptidases, carbon fixation in } \\
\text { photosynthetic organisms in cases } \\
\text { Base excision repair, glycolysis/gluconeogenesis, and biosynthesis of amino } \\
\text { acids in controls }\end{array}$ \\
\hline
\end{tabular}


Table 3. Cont.

\begin{tabular}{llll}
\hline No. & Author, Year & Sample & Microbial Functions Associated with Tumors and Controls \\
\hline 4 & Yang et al. 2018 [7] & Oral rinse & $\begin{array}{l}\text { Cytoskeleton proteins, methane metabolism, carbon fixation in } \\
\text { photosynthetic organisms, restriction enzymes in cases. } \\
\text { Amino acid synthesis and metabolism in controls } \\
\text { Proinflammatory bacterial component, such as lipopolysaccharide } \\
\text { biosynthesis; metabolism of cofactors and vitamins, such as porphyrin and } \\
\text { chlorophyll metabolism in cancer cases. } \\
\text { Methane metabolism, glucose-related metabolisms, such as } \\
\text { phosphotransferase system (PTS) and glycolysis, were significantly enriched } \\
\text { in cancer cases. } \\
\text { Xenobiotic and amine degradation in cases and sugar degradation pathways } \\
\text { in controls }\end{array}$ \\
\hline 7 & Zhou et al. 2020 [25] & Tissue & Oral brushings \\
\hline
\end{tabular}

\section{Discussion}

Oral cancer has been one of the most pervasive diseases known to the human species, with OSCC representing $90 \%$ of the cases. Although the oral cavity harbors an estimated 500 to 700 microorganisms of different species, there is inconclusive evidence on the relationship between microbiota and oral cancer [37]. In this systematic review, our objective was to critically review the studies that investigated the association of the oral microbiome with oral cancer through DNA sequencing of oral samples. Our systematic review is partly attributed to the hypothesis that certain microbial populations may be associated with the pathogenesis of oral cancer and, thus, can be utilized as an indicator for oral malignancy.

Overall results in comparison of diversity and richness between healthy and tumor tissues showed inconsistency. Microbial diversity compared between malignant and healthy tissues within the same sample showed similarity. Conversely, samples isolated from different cases and control samples displayed significant differences. However, the data obtained were not unforeseen. The concept of field cancerization can be a plausible explanation for similarities identified in the resident microbiome adjacent to premalignant or malignant tissues [38]. It is generally deemed that there is a reduction of microbial diversity in cancers, and a more diverse microbiome is associated with health [10]. However, we did not find a similar observation with microbiome studies in oral cancer. The diversity of the oral cavity environment consisting of different complex sub-niches that harbor divergent resident microbiota could be a reasonable explanation [39].

The differences in the abundances of phyla Fusobacteria, Firmicutes, and Bacteroidetes were predominant in several studies. Fusobacteria was targeted in many studies due to its potential role in colorectal cancer occurrence and progression through stimulating cell proliferation, increasing cellular migration and invasion, and inducing inflammation [40]. In addition, stimulated production of IL6 and activation of STAT3 during the incubation of F. nucleatum on OSCC cells enhanced proliferation and invasion of the cells [27]. However, the consistent presence of Fusobacterium could not be detected among the reviewed studies.

The use of consistent diagnostic criteria for the case definition was lacking among the included studies. Although samples from most of the included studies were microscopically confirmed as OSCC, the diagnostic criteria for OSCC were poorly described. The utilization of international diagnostic classification standards for all clinical and research purposes is recommended for more comparable results. The pooling of samples from the oral cavity with those from the pharynx and larynx can produce significant bias as the differences identified may be due to the microbial variations corresponding to the diverse sites [41]. The sampling strategy is to be considered carefully as different samples may hinder comparison, as the oral microbiome may differ according to the type of samples [10]. The surface samples may depict colonizing microbiome, whereas deeper tissue samples might reflect more significant microbiota that may play a potential role. Salivary samples may be reflective of the total oral environment, whereas direct sampling from tissue samples may be more representative of an endogenous microbiome co-evolving with the host [42]. 
The microbial communities collected from the mucosal surface by an oral swab may not reflect the tumor-associated microbiome $[43,44]$. The surface microbial communities may also be influenced by various factors, including salivary $\mathrm{pH}$, redox potential, and caries/periodontal status. Salivary samples could be utilized for exploring biomarkers as predictive models using multiple bacteria. Multiple multi-bacterial predictive models using the fecal microbiome have been reported to distinguish colorectal cancer patients from healthy controls, which has the potential to be validated in a new population [45]. However, only a single study has reported the utility of an oral microbiome panel in discriminating oral and oropharyngeal cancer patients from normal healthy individuals [32].

The reliability of microbiome studies largely depends on the molecular biology techniques utilized downstream. Hypervariable regions of the 16S rRNA gene and sequencing platforms play an important role in influencing the end results of the studies [46]. Most studies sequenced the V3-V4 regions, although some chose V4, V3-V5, V4-V5, and V6-V8 regions. Experimental studies have concluded that the type of $16 \mathrm{~S}$ rRNA region chosen for amplification can significantly affect the proportions of distinct taxa [10]. Apart from the choice of hypervariable regions of the 16S rRNA, the database and classifiers used will also add to the technical differences in the microbiome data [10]. Although 16S rRNA gene amplicon sequencing is cost-effective, it only provides taxonomic classification up to the genus level [47]. Characterizing the data at the genera level necessarily constrains the biological interpretations of categorized associations, as several species or even strains under the same genera may have a different impact on a particular disease.

Several different oral bacterial species have been shown to promote cell proliferation. $P$. gingivalis has been involved in the downstream signaling pathway of the transcription factor NF- $\mathrm{kB}$ and few MAPK family members including MAPK8 and MAPK14 that play an important role in oncogenesis [48]. F. nucleatum has also been shown to upregulate the Toll-like receptor (TLR) signaling and activation, of cell cycle regulators STAT3 and cyclin D1, leading to the growth of cancer cells [49]. Apart from cell proliferation, certain oral bacterial species have been shown to indirectly inhibit apoptotic pathways and increase the survival of cells [50-52]. In vitro studies have also demonstrated the impact of $P$. gingivalis and $F$. nucleatum on the upregulation of matrix metalloproteinases, including MMP-2, MMP-3, and MMP-9, which degrade the extracellular matrix and the basement membrane enabling cancer cells to invade and translocate to other sites [53]. Hence, metagenomic and meta-transcriptomics approaches to improve the taxonomical, as well as functional resolution, are the way forward.

Analyzing the results of the sequencing studies demonstrate a highly complex diversity in the oral microbiome associated with oral mucosal diseases. There has not been any consensus regarding a single genera or species that could be useful for discriminating between health and oral cancer. Therefore, comparisons of complexes of microorganisms or community-level comparisons are now being included in the analysis. Collectively, microbiome studies have established that the oral microbiome in cancer patients differs from healthy controls. Many studies have demonstrated a shift towards gram-negative bacteria which have been implicated in the pathogenesis of periodontitis, as illustrated in Table 1. The presence of periodontal disease is one of the most important confounding factors which can bring potential bias in microbiome studies on OSCC. Periodontal disease and oral cancers are both diseases of the elderly. There is increasing evidence for periodontal disease to be considered as a putative risk factor for oral cancer [4]. The possible link between these two is inflammation which is considered as the seventh hallmark of cancer [54]. The inflammatory mediators released in response to the periodontopathogenic bacteria, as well as their compositional and metabolic products, are well-known activators of pathogen recognition receptors such as toll-like receptors [55]. The prolonged exposure of mucosa to numerous chemokines and other inflammatory mediators released in chronic periodontitis may promote a favorable environment by establishing DNA damage, thereby contributing to tumorigenesis. Hence, it seems logical that the functional component of the oral microbiome is playing a more inevitable role than the phylogenetic composition. 
Microbial studies have also shown that an increase in lipopolysaccharide synthesis and altered amino acid metabolism in the microbial community in oral cancer [35]. Nevertheless, it is uncertain whether this shift can be considered as a precursor step or opportunistic colonizing of these organisms from the gingival pockets to a more enriching microenvironment. Thus, elucidating the exact role of the microbiome in the initiation and progression of oral carcinogenesis can be challenging owing to the complex niches in the oral cavity. Temporal profiling of the microbiome of potentially malignant disorders as well as their periodontal parameters longitudinally is a possible way forward to unravel this complex mystery.

A recent meta-analysis of the gut microbiome highlighted the concept of a nonspecific microbial response to be considered in all the future case-control oral microbiome studies [56]. It has been suggested that results from microbiome studies should be viewed with caution, especially for cancer studies, as most of the reported microbiome association could be suggestive of a shared response to a common symptom (ulceration, inflammation) of cancer and health rather than a cancer-specific biological difference [56]. Health-associated nonspecific bacteria are usually ubiquitous and abundant across the population, whereas disease-associated bacteria are abundant when present in disease, but not ubiquitous to the entire population. The most ubiquitous and common commensal colonizers, as well as periodontopathogenic bacteria that respond to or cause local inflammation, can be frequently present in the oral cavity of healthy controls and maybe overrepresented in periodontitis. Hence, attempts should be made to identify subsets exhibiting distinct microbial dysbiosis without such confounders to further decode the microbial-host interactions.

The microbiome may also play a plausible role in the progression of cancer, including the differentiation of the tumor, its local spread and invasiveness, as well as distant metastasis. Periodontal inflammation has been shown to induce epithelial-mesenchymal transition, which is an important element of tumor invasiveness as well as secretion of the angiogenic factors VEGF and angiogenin $[57,58]$. Therefore, clinical studies should gauge the association of the oral microbiome and other tumor characteristics like a lymphatic and perineural invasion. Moreover, parallel evidence is also required from murine studies in cancer, in which gnotobiotic mice, chemically induced or genetically predisposed to oral carcinogenesis are used to detect whether carcinogenesis can be potentiated by exposing mice to specific bacteria or saliva from oral cancer patients. A recent study using germfree mice illustrated that the presence of various bacterial taxa enhanced tumorigenesis potential and enhanced the number of tumors in the mice [59]. Moreover, the communitywide metabolic profiles of the microbiome showed that the same metabolic activities were consistently associated with OSCC irrespective of the microbial composition [59].

\section{Conclusions}

Based on current evidence, we can conclude that there is significant dysbiosis in the phylogenetic composition of the oral microbiome on oral cancer patients. However, there aren't any particular genera or species of bacteria to be highlighted to have a significant contribution to oral tumorigenesis. It could be hypothesized that a critical element in elucidating the contribution of oral microbiome to oral carcinogenesis would be the collective functions of the microbial community, thus accounting for the absence of a consensus on the microbial profile in OSCC.

Hence, a functional approach through meta-transcriptomics might be the way forward to identify the contributory role of the oral microbiome in oral carcinogenesis and its influences on the behavior of the neoplasm. In addition, host-microbial interactions could also pave the way in enhancing our understanding of the tumor's microbial community. The oral microbiome has been known to exhibit variations between individuals and within the same individual. Further, we have a limited understanding of the dynamics of the oral microbiome as well. Thus, without baseline data on the oral microbiome of the same individual in health, the translational aspect of cancer microbiome studies might still be inconclusive. Moreover, it is also important to consider the role of phages, archaea, and fungi in oral health and diseases. Functions and potential roles need to be explored as 
research into those topics are still in the infancy stage and functional evidence is essential to expand the current insights into meaningful conclusions.

Translation of murine studies to humans is also challenging as the microbiome significantly differs between humans and mice. Standardization and repeatability of oral microbiome research is another question that calls for researchers to work on a global level for standardization in oral microbiome research. Therefore, it is fair to presume that oral microbiome research, unlike gut microbiome research, is still far away from translation; more systematic studies with integrated methods are needed to determine the potential mechanisms and role of the oral microbiome in oral cancers and other diseases. Even though we have accumulated evidence on the strong association between microbiome and cancer, we also need to expand the microbiome research into bacterial species and genes to gain insight into the exact role of microorganisms in the causality as well as the progression of a tumor.

If the potential involvement of the oral microbiome in the progression of oral cancer can be completely elucidated, analysis of the microbiome would become a useful indicator of the efficacy of chemotherapy, radiotherapy, and immunotherapy. Collectively, all the observational studies have offered an invaluable understanding of oral microbiome composition in oral cancer patients; however, if we are to translate this for clinical use, we should work on developing our understanding of the utility of oral microbiome manipulation by emphasizing interventional research with clinical impact.

Supplementary Materials: The following are available online at https://www.mdpi.com/article/10 .3390/ijerph18147224/s1, Table S1: search results, Table S2: New castle ottawa risk of bias (adjusted).

Author Contributions: Conceptualization, D.G.; methodology, D.G.; formal analysis, L.S.M., S.W.L., G.K.Y.S., C.H.Y., K.C.Y. and L.K.L. resources and data curation, L.S.M., S.W.L., G.K.Y.S., C.H.Y., K.C.Y. and L.K.L.; writing-original draft preparation, L.S.M., S.W.L., G.K.Y.S., C.H.Y., K.C.Y., L.K.L. and D.G. Writing-D.G.; supervision, D.G.; project administration, D.G. All authors have read and agreed to the published version of the manuscript.

Funding: The APC was funded by International Medical University Malaysia.

Institutional Review Board Statement: Not applicable.

Informed Consent Statement: Not applicable.

Data Availability Statement: Not applicable.

Acknowledgments: The authors would like to acknowledge that the work was undertaken as part of the selective "Bioinformatics in Oral health care" in the Selective module of the dental undergraduate curriculum in the International Medical University Malaysia.

Conflicts of Interest: The authors declare no conflict of interest.

\section{References}

1. Fitzsimonds, Z.; Rodriguez-Hernandez, C.; Bagaitkar, J.; Lamont, R. From Beyond the Pale to the Pale Riders: The Emerging Association of Bacteria with Oral Cancer. J. Dent. Res. 2020, 99, 604-612. [CrossRef]

2. Siegel, R.; Ma, J.; Zou, Z.; Jemal, A. Cancer Statistics, 2010. CA Cancer J. Clin. 2010, 70, 7-30. [CrossRef]

3. Conway, D.I.; Purkayastha, M.; Chestnutt, I.G. The changing epidemiology of oral cancer: Definitions, trends, and risk factors. Br. Dent. J. 2018, 225, 867-873. [CrossRef]

4. Gopinath, D.; Kunnath Menon, R.K.; Veettil, S.; George Botelho, M.; Johnson, N.W. Periodontal Diseases as Putative Risk Factors for Head and Neck Cancer: Systematic Review and Meta-Analysis. Cancers 2020, 12, 1893. [CrossRef]

5. Gopinath, D.; Thannikunnath, B.V.; Neermunda, S.F. Prevalence of Carcinomatous Foci in Oral Leukoplakia: A Clinicopathologic Study of 546 Indian Samples. J. Clin. Diagn. Res. 2016, 10, ZC78-ZC83. [CrossRef] [PubMed]

6. Warnakulasuriya, S.; Kujan, O.; Aguirre-Urizar, J.M.; Bagan, J.V.; González-Moles, M.Á.; Kerr, A.R.; Lodi, G.; Mello, F.W.; Monteiro, L.; Ogden, G.R.; et al. Oral potentially malignant disorders: A consensus report from an international seminar on nomenclature and classification, convened by the WHO Collaborating Centre for Oral Cancer. Oral Dis. 2020. [CrossRef]

7. Yang, C.-Y.; Yeh, Y.-M.; Yu, H.-Y.; Chin, C.-Y.; Hsu, C.-W.; Liu, H.; Huang, P.-J.; Hu, S.-N.; Liao, C.-T.; Chang, K.-P.; et al. Oral Microbiota Community Dynamics Associated with Oral Squamous Cell Carcinoma Staging. Front. Microbiol. $2018,9,862$. [CrossRef] [PubMed] 
8. Karpiński, T.M. Role of Oral Microbiota in Cancer Development. Microorganisms 2019, 7, 20. [CrossRef] [PubMed]

9. Elsland, D.; Neefjes, J. Bacterial infections and cancer. EMBO Rep. 2018, 19, e46632. [CrossRef]

10. Gopinath, D.; Menon, R.K.; Banerjee, M.; Yuxiong, R.S.; Botelho, M.G.; Johnson, N.W. Culture-independent studies on bacterial dysbiosis in oral and oropharyngeal squamous cell carcinoma: A systematic review. Crit. Rev. Oncol. 2019, 139, 31-40. [CrossRef]

11. Bjerre, R.; Bandier, J.; Skov, L.; Engstrand, L.; Johansen, J.D. The role of the skin microbiome in atopic dermatitis: A systematic review. Br. J. Dermatol. 2017, 177, 1272-1278. [CrossRef]

12. Pushalkar, S.; Mane, S.; Ji, X.; Li, Y.; Evans, C.; Crasta, O.R.; Morse, D.; Meagher, R.; Singh, A.; Saxena, D. Microbial diversity in saliva of oral squamous cell carcinoma. FEMS Immunol. Med. Microbiol. 2011, 61, 269-277. [CrossRef]

13. Schmidt, B.L.; Kuczynski, J.; Bhattacharya, A.; Huey, B.; Corby, P.M.; Queiroz, E.L.S.; Nightingale, K.; Kerr, A.R.; DeLacure, M.D.; Veeramachaneni, R.; et al. Changes in abundance of oral microbiota associated with oral cancer. PLoS ONE 2014, 9 , e98741. [CrossRef]

14. Guerrero-Preston, R.; Godoy-Vitorino, F.; Jedlicka, A.; Rodríguez-Hilario, A.; González, H.; Bondy, J.; Lawson, F.; Folawiyo, O.; Michailidi, C.; Dziedzic, A.; et al. 16S rRNA amplicon sequencing identifies microbiota associated with oral cancer, human papilloma virus infection and surgical treatment. Oncotarget 2016, 7, 51320-51334. [CrossRef]

15. Guerrero-Preston, R.; White, J.R.; Godoy-Vitorino, F.; Rodriguez-Hilario, A.; Navarro, K.; Gonzalez, H.; Michailidi, C.; Jedlicka, A.; Canapp, S.; Bondy, J.; et al. High-resolution microbiome profiling uncovers Fusobacterium nucleatum, Lactobacillus gasseri/johnsonii, and Lactobacillus vaginalis associated to oral and oropharyngeal cancer in saliva from HPV positive and HPV negative patients treated with surgery and chemo-radiation. Oncotarget 2017, 8, 110931-110948.

16. Banerjee, S.; Tian, T.; Wei, Z.; Peck, K.N.; Shih, N.; Chalian, A.A.; O’Malley, B.W.; Weinstein, G.S.; Feldman, M.D.; Alwine, J.; et al. Microbial Signatures Associated with Oropharyngeal and Oral Squamous Cell Carcinomas. Sci. Rep. 2017, 7, 4036. [CrossRef]

17. Bornigen, D.; Ren, B.; Pickard, R.; Li, J.; Ozer, E.; Hartmann, E.M.; Xiao, W.; Tickle, T.; Rider, J.; Gevers, D.; et al. Alterations in oral bacterial communities are associated with risk factors for oral and oropharyngeal cancer. Sci. Rep. 2017, 7, 17686. [CrossRef] [PubMed]

18. Hayes, R.B.; Ahn, J.; Fan, X.; Peters, B.A.; Ma, Y.; Yang, L.; Agalliu, I.; Burk, R.D.; Ganly, I.; Purdue, M.P.; et al. Association of oral microbiome with risk for incident head and neck squamous cell cancer. JAMA Oncol. 2018, 4, 358-365. [CrossRef] [PubMed]

19. Shin, J.M.; Luo, T.; Kamarajan, P.; Fenno, J.C.; Rickard, A.H.; Kapila, Y.L. Microbial Communities Associated with Primary and Metastatic Head and Neck Squamous Cell Carcinoma-A High Fusobacterial and Low Streptococcal Signature. Sci. Rep. 2017, 7, 9934. [CrossRef] [PubMed]

20. Ganly, I.; Yang, L.; Giese, R.A.; Hao, Y.; Nossa, C.W.; Morris, L.G.T.; Rosenthal, M.; Migliacci, J.; Kelly, D.; Tseng, W.; et al. Periodontal pathogens are a risk factor of oral cavity squamous cell carcinoma, independent of tobacco and alcohol and human papillomavirus. Int. J. Cancer 2019, 145, 775-784. [CrossRef]

21. Sharma, A.K.; DeBusk, W.T.; Stepanov, I.; Gomez, A.; Khariwala, S.S. Oral Microbiome Profiling in Smokers with and without Head and Neck Cancer Reveals Variations Between Health and Disease. Cancer Prev. Res. 2020, 13, 463-474. [CrossRef] [PubMed]

22. Zhao, H.; Chu, M.; Huang, Z.; Yang, X.; Ran, S.; Hu, B.; Zhang, C.; Liang, J. Variations in oral microbiota associated with oral cancer. Sci. Rep. 2017, 7, 11773. [CrossRef]

23. Chang, C.; Geng, F.; Shi, X.; Li, Y.; Zhang, X.; Zhao, X.; Pan, Y. The prevalence rate of periodontal pathogens and its association with oral squamous cell carcinoma. Appl. Microbiol. Biotechnol. 2018, 103, 1393-1404. [CrossRef] [PubMed]

24. Zhang, L.; Liu, Y.; Zheng, H.J.; Zhang, C.P. The Oral Microbiota May Have Influence on Oral Cancer. Front. Cell. Infect. Microbiol. 2020, 9, 476. [CrossRef]

25. Zhou, J.; Wang, L.; Yuan, R.; Yu, X.; Chen, Z.; Yang, F.; Sun, G.; Dong, Q. Signatures of Mucosal Microbiome in Oral Squamous Cell Carcinoma Identified Using a Random Forest Model. Cancer Manag. Res. 2020, 12, 5353-5363. [CrossRef] [PubMed]

26. Lee, W.-H.; Chen, H.-M.; Yang, S.-F.; Wen-Liang, C.; Peng, C.-Y.; Tzu-Ling, Y.; Tsai, L.-L.; Wu, B.-C.; Hsin, C.-H.; Huang, C.-N.; et al. Bacterial alterations in salivary microbiota and their association in oral cancer. Sci. Rep. 2017, 7, 16540. [CrossRef]

27. Hsiao, J.-R.; Chang, C.-C.; Lee, W.-T.; Huang, C.-C.; Ou, C.-Y.; Tsai, S.-T.; Chen, K.-C.; Huang, J.-S.; Wong, T.-Y.; Lai, Y.-H.; et al. The interplay between oral microbiome, lifestyle factors and genetic polymorphisms in the risk of oral squamous cell carcinoma. Carcinogens 2018, 39, 778-787. [CrossRef]

28. Panda, M.; Rai, A.K.; Rahman, T.; Das, A.; Das, R.; Sarma, A.; Kataki, A.C.; Chattopadhyay, I. Alterations of salivary microbial community associated with oropharyngeal and hypopharyngeal squamous cell carcinoma patients. Arch. Microbiol. 2019, 202, 785-805. [CrossRef] [PubMed]

29. Rai, A.K.; Panda, M.; Das, A.K.; Rahman, T.; Das, R.; Das, K.; Sarma, A.; Kataki, A.C.; Chattopadhyay, I. Dysbiosis of salivary microbiome and cytokines influence oral squamous cell carcinoma through inflammation. Arch. Microbiol. 2021, 203, 137-152. [CrossRef] [PubMed]

30. Al-Hebshi, N.N.; Nasher, A.T.; Maryoud, M.Y.; Homeida, H.E.; Chen, T.; Idris, A.M.; Johnson, N.W. Inflammatory bacteriome featuring Fusobacterium nucleatum and Pseudomonas aeruginosa identified in association with oral squamous cell carcinoma. Sci. Rep. 2017, 7, 1834. [CrossRef]

31. Mok, S.F.; Karuthan, C.; Cheah, Y.K.; Ngeow, W.C.; Rosnah, Z.; Yap, S.F.; Ong, H.K.A. The oral microbiome community variations associated with normal, potentially malignant disorders and malignant lesions of the oral cavity. Malays. J. Pathol. 2017, 39, 1-15.

32. Lim, Y.; Fukuma, N.; Totsika, M.; Kenny, L.; Morrison, M.; Punyadeera, C. The Performance of an Oral Microbiome Biomarker Panel in Predicting Oral Cavity and Oropharyngeal Cancers. Front. Cell. Infect. Microbiol. 2018, 8, 267. [CrossRef] 
33. Hashimoto, K.; Shimizu, D.; Hirabayashi, S.; Ueda, S.; Miyabe, S.; Oh-Iwa, I.; Nagao, T.; Shimozato, K.; Nomoto, S. Changes in oral microbial profiles associated with oral squamous cell carcinoma vs leukoplakia. J. Investig. Clin. Dent. 2019, 10 , e12445. [CrossRef]

34. Takahashi, Y.; Park, J.; Hosomi, K.; Yamada, T.; Kobayashi, A.; Yamaguchi, Y.; Iketani, S.; Kunisawa, J.; Mizuguchi, K.; Maeda, N.; et al. Analysis of oral microbiota in Japanese oral cancer patients using 16S rRNA sequencing. J. Oral Biosci. 2019, 61, 120-128. [CrossRef] [PubMed]

35. Perera, M.; Al-Hebshi, N.; Perera, I.; Ipe, D.; Ulett, G.; Speicher, D.; Chen, T.; Johnson, N. Inflammatory Bacteriome and Oral Squamous Cell Carcinoma. J. Dent. Res. 2018, 97, 725-732. [CrossRef]

36. Vesty, A.; Gear, K.; Biswas, K.; Radcliff, F.J.; Taylor, M.W.; Douglas, R.G. Microbial and inflammatory-based salivary biomarkers of head and neck squamous cell carcinoma. Clin. Exp. Dent. Res. 2018, 4, 255-262. [CrossRef] [PubMed]

37. Dewhirst, F.E.; Chen, T.; Izard, J.; Paster, B.J.; Tanner, A.C.R.; Yu, W.-H.; Lakshmanan, A.; Wade, W.G. The Human Oral Microbiome. J. Bacteriol. 2010, 192, 5002-5017. [CrossRef]

38. Mohan, M.; Jagannathan, N. Oral field cancerization: An update on current concepts. Oncol. Rev. 2014, 8, 244. [CrossRef]

39. Whisner, C.; Aktipis, C.A. The Role of the Microbiome in Cancer Initiation and Progression: How Microbes and Cancer Cells Utilize Excess Energy and Promote One Another's Growth. Curr. Nutr. Rep. 2019, 8, 42-51. [CrossRef] [PubMed]

40. Sun, C.-H.; Li, B.-B.; Wang, B.; Zhao, J.; Zhang, X.-Y.; Li, T.-T.; Li, W.-B.; Tang, D.; Qiu, M.-J.; Wang, X.-C.; et al. The role of Fusobacterium nucleatum in colorectal cancer: From carcinogenesis to clinical management. Chronic Dis. Transl. Med. 2019, 5, 178-187. [CrossRef] [PubMed]

41. Gopinath, D.; Menon, R.K. Unravelling the molecular signatures in HNSCC: Is the homogenous paradigm becoming obsolete? Oral Oncol. 2018, 82, 195. [CrossRef]

42. Gopinath, D.; Menon, R.K.; Wie, C.C.; Banerjee, M.; Panda, S.; Mandal, D.; Behera, P.K.; Roychoudhury, S.; Kheur, S.; Botelho, M.G.; et al. Salivary bacterial shifts in oral leukoplakia resemble the dysbiotic oral cancer bacteriome. J. Oral Microbiol. 2021, 13, 1857998. [CrossRef]

43. Gopinath, D.; Menon, R.K.; Wie, C.C.; Banerjee, M.; Panda, S.; Mandal, D.; Behera, P.K.; Roychoudhury, S.; Kheur, S.; Botelho, M.G.; et al. Differences in the bacteriome of swab, saliva, and tissue biopsies in oral cancer. Sci. Rep. 2021, 11, 1181. [CrossRef] [PubMed]

44. Gopinath, D.; Menon, R.K. Increasing Reproducibility in Oral Microbiome Research. In Oral Microbiome. Methods in Molecular Biology; Adami, G., Ed.; Humana Press: New York, NY, USA, 2021; in press.

45. Huybrechts, I.; Zouiouich, S.; Loobuyck, A.; Vandenbulcke, Z.; Vogtmann, E.; Pisanu, S.; Iguacel, I.; Scalbert, A.; Indave, I.; Smelov, V.; et al. The Human Microbiome in Relation to Cancer Risk: A Systematic Review of Epidemiologic Studies. Cancer Epidemiol. Biomark. Prev. 2020, 29, 1856-1868. [CrossRef] [PubMed]

46. Menon, R.K.; Gopinath, D. Eliminating bias and accelerating the clinical translation of oral microbiome research in oral oncology. Oral Oncol. 2018, 79, 84-85. [CrossRef] [PubMed]

47. Tremblay, J.; Singh, K.; Fern, A.; Kirton, E.S.; He, S.; Woyke, T.; Lee, J.; Chen, F.; Dangl, J.L.; Tringe, S.G. Primer and platform effects on 16S rRNA tag sequencing. Front. Microbiol. 2015. [CrossRef] [PubMed]

48. Groeger, S.; Jarzina, F.; Domann, E.; Meyle, J. Porphyromonas gingivalis activates NFkB and MAPK pathways in human oral epithelial cells. BMC Immunol. 2017, 18, 1-11. [CrossRef] [PubMed]

49. Gallimidi, A.B.; Fischman, S.; Revach, B.; Bulvik, R.; Maliutina, A.; Rubinstein, A.M.; Nussbaum, G.; Elkin, M. Periodontal pathogens Porphyromonas gingivalis and Fusobacterium nucleatum promote tumor progression in an oral-specific chemical carcinogenesis model. Oncotarget 2015, 6, 22613-22623. [CrossRef] [PubMed]

50. Yao, L.; Jermanus, C.; Barbetta, B.; Choi, C.; Verbeke, P.; Ojcius, D.M.; Yilmaz, Ö. Porphyromonas gingivalis infection sequesters pro-apoptotic Bad through Akt in primary gingival epithelial cells. Mol. Oral Microbiol. 2010, 25, 89-101. [CrossRef] [PubMed]

51. Yilmaz, O.; Jungas, T.; Verbeke, P.; Ojcius, D.M. Activation of the Phosphatidylinositol 3-Kinase/Akt Pathway Contributes to Survival of Primary Epithelial Cells Infected with the Periodontal Pathogen Porphyromonas gingivalis. Infect. Immun. 2004, 72, 3743-3751. [CrossRef] [PubMed]

52. Asoudeh-Fard, A.; Barzegari, A.; Dehnad, A.; Bastani, S.; Golchin, A.; Omidi, Y. Lactobacillus plantarum induces apoptosis in oral cancer KB cells through upregulation of PTEN and downregulation of MAPK signalling pathways. BioImpacts 2017, 7, 193-198. [CrossRef]

53. Abdulkareem, A.; Shelton, R.M.; Landini, G.; Cooper, P.; Milward, M.R. Periodontal pathogens promote epithelial-mesenchymal transition in oral squamous carcinoma cells in vitro. Cell Adhes. Migr. 2017, 12, 127-137. [CrossRef]

54. Li, S.; Liu, X.; Zhou, Y.; Acharya, A.; Savkovic, V.; Xu, C.; Wu, N.; Deng, Y.; Hu, X.; Li, H.; et al. Shared genetic and epigenetic mechanisms between chronic periodontitis and oral squamous cell carcinoma. Oral Oncol. 2018, 86, 216-224. [CrossRef]

55. Kamarajan, P.; Ateia, I.; Shin, J.M.; Fenno, J.C.; Le, C.; Zhan, L.; Chang, A.; Darveau, R.; Kapila, Y.L. Periodontal pathogens promote cancer aggressivity via TLR/MyD88 triggered activation of Integrin/FAK signaling that is therapeutically reversible by a probiotic bacteriocin. PLOS Pathog. 2020, 16, e1008881. [CrossRef] [PubMed]

56. Duvallet, C.; Gibbons, S.M.; Gurry, T.; Irizarry, R.A.; Alm, E.J. Meta-analysis of gut microbiome studies identifies disease-specific and shared responses. Nat. Commun. 2017, 8, 1784. [CrossRef] [PubMed] 
57. Abdulkareem, A.A.; Shelton, R.M.; Landini, G.; Cooper, P.R.; Milward, M.R. Potential role of periodontal pathogens in compromising epithelial barrier function by inducing epithelial-mesenchymal transition. J. Periodontal Res. 2018, 53, 565-574. [CrossRef] [PubMed]

58. Dominguez, C.; David, J.M.; Palena, C. Epithelial-mesenchymal transition and inflammation at the site of the primary tumor. Semin. Cancer Biol. 2017, 47, 177-184. [CrossRef]

59. Stashenko, P.; Yost, S.; Choi, Y.; Danciu, T.; Chen, T.; Yoganathan, S.; Kressirer, C.; Ruiz-Tourrella, M.; Das, B.; Kokaras, A.; et al. The Oral Mouse Microbiome Promotes Tumorigenesis in Oral Squamous Cell Carcinoma. mSystems 2019, 4, e00323-19. [CrossRef] 